\title{
THE EARLY BUDDHIST HERITAGE OF LADAKH RECONSIDERED
}

\section{CHRISTIAN LUGZANTTS}

Much of what is generally considered to represent the earliest heritage of Ladakh cannot be securely dated. It even cannot be said with certainty when Buddhism reached Ladakh. Similarly, much of what is recorded in inscriptions and texts concerning the period preceding the establishment of the Ladakhi kingdom in the late $15^{\text {th }}$ century is either fragmentary or legendary. Thus, only a comparative study of these records together with the architectural and artistic heritage can provide more secure glimpses into the early history of Buddhism in Ladakh.

This study outlines the most crucial historical issues and questions from the point of view of an art historian and archaeologist, drawing on a selection of exemplary monuments and objects, the historical value of which has in many instances yet to be exploited. Without aiming to be so comprehensive, the article updates the groundbreaking work of A.H. Francke (particularly 1914, 1926) and Snellgrove \& Skorupski $(1977,1980)$ regarding the early Buddhist cultural heritage of the central region of Ladakh on the basis that the Alchi group of monuments ${ }^{1}$ has to be attributed to the late 12 and early $13^{\text {th }}$ centuries $A D$ rather than the $11^{\text {th }}$ or $12^{\text {th }}$ centuries as previously assumed (Goepper 1990). It also collects support for the new attribution published by different authors since Goepper's primary article.

The now fairly secure attribution of the Alchi group of monuments shifts the dates by only one century, ${ }^{2}$ but has wide repercussions on

1 This term refers to the early monuments of Alchi, Mangyu and Sumda, which are located in a narrow geographic area, have a common social, cultural and artistic background, and may be attributed to within a relatively narrow timeframe.

${ }^{2}$ After assessing the inscriptions of the Alchi monuments, Snellgrove \& Skorupski (1977:15, 79-80) cautiously attributed the monuments to a period after the life-time of Rinchen Zangpo (Rin-chen-bzang-po; 958-1055) and within the context of a small regional dominion. They nevertheless considered the art of Alchi to be an immediate rcsult of the West Tibetan kingdom that introduced organised Buddhism in the area. 
our perception of the earliest Ladakhi Buddhist heritage and its development up to the late $15^{\text {th }}$ century. ${ }^{3}$ More importantly, the new dates make it possible to link the early Buddhist heritage in Ladakh to the general development of Tibetan Buddhism and thus also has major effects on our understanding of early Tibetan art history.

\section{Pre-Alchi heritage}

None of the many Buddhist monuments in Ladakh appears to preserve anything that makes it possible to attribute it to the phase when Ladakh first came into contact with Buddhism. Among the stupas, Sani is traditionally associated with the time of the Kuṣaña king Kaniska I. ${ }^{4}$ The claim that Buddhism reached Ladakh at the time of the Kușannas can neither be supported nor refuted: there is simply no surviving evidence. ${ }^{5}$ The chörten at Sani, as it stands today, certainly does not support this claim. ${ }^{6}$

Nevertheless, it may be safe to presume that by the time the Tibetans assumed control of the region as early as 663, the Ladakhis, or rather the Dards that are thought to have inhabited the area, had at least come into contact with Buddhism. ${ }^{7}$ The earliest evidence of Buddhism in the region may be represented by the stupa engravings found at different sites, mainly at crossing places along the principal

They suggested that the Alchi Dukhang may have been built in the second half of the $11^{\text {th }}$ century at the earliest and the later monuments of the group in the $12^{\text {th }}$ century.

3 This may be one of the main reasons why a number of scholars do not yet accept the new dates.

${ }^{4}$ Most commonly the Kanișa era is thought to have commenced around $100 \mathrm{AD}$, the range from $78 \mathrm{AD}$ (i.e, the beginning of the Saka era) to ca. $130 \mathrm{AD}$ being most frequently mentioned.

3 Of course, the Kharosti inscription of Uvima Kavthisa (Wima Kadphises) found near the Kaltse (Kha-la-rtse) bridge proves that at least lower Ladakh at one stage was part of the Kusaña empire (Petech 1977:6-7).

${ }^{6}$ Cf. e.g. the report in Snellgrove \& Skorupski (1980:6, 57-61, Figs.4,18).

7 The date of 663 for the Tibetan occupation of the region west of Ladakh, at that time called Great and Little Balur (also Bolor), is suggested by the extensive study of Beckwith (1987:29 31) while Petech (1977:9-13) maintained a later date (720/1) for the area coming under Tibetan control. The report of Xuanzang (Hsuan-tsang) a century earlier remains unclear with regard to Buddhism in the area, but the report of the $8^{\mathrm{t}}$ century Korean pilgrim Hye $\mathrm{Ch}^{\prime} \mathrm{O}$ (Hyecho, Hui-ch'ao), who travelled through northern India and Central Asia between 724 and 727 , implies that at that time the Baltistan region and Zhang-zhung were at least partly Buddhist and under Tibetan rule (Petech 1977:10), but that the Tibetans were not yet Buddhist (Yang, Han-sung, Yün-hua Jan, Shotaro lida, and Laurence W. Preston. 1984; see also note 9\%. 
rivers. ${ }^{8}$ On the basis of accompanying inscriptions, at least some of these stupa engravings in the upper Indus region that is in presentday Ladakh and West Tibet-can be attributed to the Tibetan occupation. ${ }^{9}$ It can only be hoped that future research will provide us with more definitive evidence. ${ }^{10}$

A major lacuna regarding the early Buddhist artistic heritage of Ladakh is a detailed study of the numerous rock carvings found in the region and neighbouring areas. ${ }^{1}$ These carvings are placed either on large rock boulders along pathways, such as those of Choglamsar, Mulbek, Shey or Suru, or on slim stone steles (rdo-ring). Although some of the major carvings have inscriptions carved beside them, their fragmentary state does not give secure clues to their historical setting. This means that the primary assessment of these carvings is based on historical assumptions and associations, often combined with an evaluation on the basis of art historical criteria. ${ }^{12}$ Generally, rock carvings tend to be attributed to comparatively early dates. ${ }^{13}$ It is

"Incidentally, the Wima Kadphises inscription mentioned in note 5 is also placed at such a spot.

9 To my knowledge, only two inscriptions near Kaltse (Denwood \& Howard 1990) and the inscriptions accompanying the engravings at the Alchi bridge (Denwood 1980; Orofino 1990) have been reconsidered since the groundbreaking work of A.H. Francke. Some of these inscriptions are attributed to the time of the Tibetan occupation of the region which lasted at least until the middle of the $9^{\text {th }}$ century.

By contrast, a good part of the engravings further down the Indus valley, in particular those at different sites around Chilas, considerably predate the Tibetan occupation of the region. Further, it is well known that at the time this region had a thriving Buddhist culture dating back to the Kusaña period. At the $11^{\text {th }}$ LAI.S colloquium in July 2003, Harald Hauptmann, the present director of the comprehensive research project recording and publishing the rock engravings of Northern Pakistan, presented an overview of the finds and the present state of research on that topic. Further information and references to their extensive publications are found on the project website (www.haw.baden-wuerttemberg.de).

10 It is fortunate that a team of Indian and Ladakhi scholars has taken up the task of documenting and studying Ladakhi rock engravings, which range from the ibexes and symbols to figurative and stupa representations. The first results of this project were presented at the $11^{\text {th }}$ IALS colloquium in 2003.

11 In contrast to the engravings just discussed, the carvings are commonly larger in size and attempt to show the depicted deity in relief or even three dimensions.

${ }^{12}$ However, strictly speaking, art history is only possible when a considerable body of evidence can be compared with each other, and dates can only be suggested when some of this material has a secure context (Luczanits 2001). Neither is the case with the rock carvings in Ladakh.

${ }^{13}$ Snellgrove \& Skorupski (1980:9) maintain that the carvings of Mulbek, Dras and Changspa are all $7^{\text {th }}$ to $10^{\text {th }}$ century. The Maitreya in Kartse (dKar-rtse) is considered 
important to keep in mind that these early dates have been proposed on the assumption that such sophisticated monuments as those at Alchi had already been built by the $11^{\text {th }}$ century.

The famous rock relief at Mulbek can serve as an example. ${ }^{14}$ Quite possibly, future studies will reveal that four-armed images of Maitreya of this type are a relatively late feature in Kashmir-influenced art, the Alchi Sumtsek representing a particularly significant and late example. Also, stylistic comparison does not contradict a later date - such as the $11^{\text {th }}$ century - for the Mulbek relief, but its possible range has still to be worked out. Indeed, an art-historical reassessment of this and other relief carvings, such as those of Dras ${ }^{15}$ and Suru, will only be possible once a more secure chronology for comparative pieces - in particular the Kashmiri bronzes and their western Himalayan successors-has been established. ${ }^{16}$

The most prominent example of the stone steles is the exceptionally large one near the Changspa chörten in Leh. The massive stone has a standing teaching Buddha on one face Francke 1914: pl.xxxii,a; Snellgrove \& Skorupski 1980: Fig.109), and a four-armed Avalokiteśvara ${ }^{17}$ accompanied by a small image of Hayagriva on the other

"almost identical to the the one at Mulbek" (Snellgrove \& Skorupski 1980: Figs.7,9) and also the six-armed Avalokitcśvara accompanied by two goddesses at Byama Kumbhu near Sanku "must have been executed prior to the Tibctan occupation of Western Tibet" (Snellgrove \& Skorupski 1980: Fig.2), probably because this carving is most closely comparable to the art of Kashmir. It is interesting to note that it has not been considered a contradiction that monuments were decorated by Kashmiri artists during the West Tibetan kingdom, while large scale rock carvings must precede this period or even the first Tibetan occupation due to their close association to the art of Kashmir. However, in the case of rock carvings, the Kashmir affiliation is often not as clearly articulated as generally assumed.

1t Cf. e.g. Francke $(1905,1914,1926)$, Uhlig (1976:13) the picture shows the rock with the image before the temple was built there and the image is atributcd to the $6 / 7^{\text {t }}$ centuries; Snellgrove \& Skorupski (1977:1 "7th century or later", Fig.4); Fontein (1979); and Fisher (1989).

15 Snellgrove \& Skorupski 1977: Fig. 3.

16 The attribution of Kashmiri bronzes is still tentative. Most remarkably, no bronzes are attributed to the $12^{\mathrm{h}}$ century although $\mathrm{Kashmir}$ culture was still extremely active in this period. Both the chronicles of Kashmir, the Rajatarangini (Stein 1900, and the Alchi group of monuments provide cvidence in this regard.

The important early relief on the rock below the castle of Shey (c.g. Snellgrove \& Skorupski 1977: Fig.5), executed in a much more provincial style than that at Mulbek, has to be reconsidered according to iconographic rather than stylistic criteria.

17 Holding a lotus and performing varadamadra with the right hands and holding an unidentifed object and probably a noose in the left hand, this image represents a form of Avalokitesvara unusual in the western Himalayas. 
(Francke 1914: pl.xxxii,b). Hayagriva leans on a club with both hands, a type of depicting a fierce deity that Linrothe (1999) classifies as an early feature. Again, a more detailed study of these characteristics-along with the donor and stupa representations on the stone-will be necessary to evaluate its historical context fully. ${ }^{18}$

Shey village and its surroundings house a number of interesting smaller steles (rdo-ring) which can be considered exemplary for this type of image. In the past decade, I have documented numerous such steles throughout Ladakh (e.g. Francke 1914: pl.xxxiv), and also in Lahul, but these still await a detailed study.

Similarly, a secure date cannot be forwarded for any surviving stupa, some of which are occasionally considered to predate the West Tibetan kingdom. The monumental structure at Tisseru near Leh has been associated with the assumed earliest Buddhist occupation of Ladakh, but it is not even clear if it was originally meant to be a stupa. This building is certainly most enigmatic, with its original appearance distorted not only by a long history of renovation and decay, but also by its reconstruction. ${ }^{19}$ Similarly, in the case of other chörten, in particular those of the Many Auspicious Doors-type (bKra-shis-sgomang-mchod-rten), no clues can be forwarded regarding their construction date. ${ }^{20}$

We reach more secure historical ground with the West Tibetan kingdom founded by descendants of the Central Tibetan monarchy in the region of Purang, south of mount Kailash. ${ }^{2 !}$ It is certain that during the late $10^{\mathrm{h}}$ and the beginning of the $11^{\text {th }}$ century this kingdom

18 Filigenzi (1999) places this relief in a suecession of earlier images found in northern Pakistan.

19 Apparently, an earlier structure was used for a large stupa by King Grags-'bumlde in the $15^{\text {th }}$ century. This structure then looked like a stupa from outside and had many interior chapels (Snellgrove \& Skorupski 1977: Figs.73,82), Without carlier documentation and excavation reports (if they exist), the current remains do not permit any conclusion as to the purpose and historical context of this structure. It would certainly be interesting to collect all material regarding the Tisseru monument and see what one can come up with, but it is far from certain that this would yield any result at all.

20 The best known of these are the chörten at Changspa, Leh, and at Shey, but similar, more ruined structures can also be found at Alchi and Basgo. The very fragmentary murals in some of the cells of the Alchi chörten certainly suggest an attribution to $\mathrm{c}$, the $14^{\text {in }}$ century at the earliest for this structure. Incidentally, in Central Tibet this type of structure was particularly popular in the $15^{\text {it }}$ century with the Kumbum of Gyantse being the most prominent example.

21 Snellgrove \& Skorupski (1977: 15) speak of the first important cultural impact in this regard. 
included a large part of Ladakh. Right at the beginning of this period, the monastery of Nyarma (Nyar-ma, also Nyer-ma), a few kilometres east of Tiksey (Khrigs-se), was founded as one of three major monastic foundations located in the main regions of the kingdom. ${ }^{22}$

Nyarma is today an extensive ruin that still contains part of a large surrounding wall, the sacred enclosure (chos-'khor), several ruins of large temple structures, and many chörten in different states of preservation. ${ }^{23}$ The monastery, situated on the plain of the Indus valley, apparently was abandoned only a few centuries after its foundation due to damage sustained from war and flooding. ${ }^{24}$ Some of the structures contain the remains of former clay sculptures in the form of fragmentary aureoles. These fragments are no doubt of considerable antiquity, and the absence of mural traces underneath the remains of the sculptures may indicate that they derive from the foundation period of the temple itself, but they do not give any clue as to when the temple was founded. ${ }^{25}$

A more definite attribution can be suggested for the ruin near Basgo, which was published by Francke (1914:xxv,b). This structure preserves the plugholes and halo remains of the deities of a Vajradhatumandala distributed on the back and the side walls (Fig.5). As in the Tabo main temple (Klimburg-Salter 1997), the central Vairocana with the four accompanying goddesses must have occupied a throne in the centre of the room. On the back wall, two Jinas are each accompanied by four attendant Bodhisattvas, and four offering goddesses have been placed between them, the different deities clearly differentiated by the respective sizes of the halos (Fig.6). On the side-

22. Sec Luczanits (2004:29-32) on the three major foundations and what is left of them today.

23 Besides Panglung (1983), Kath Howard (1995) has discussed Nyarma. The Austrian research project on the early Buddhist architecture in the western Himalayas led by Holger Neuwirth has also made a detailed survey of Nyarma. Gerald Koczic, former member of this research project, discussed the architecture of Nyarma at the $10^{\text {h }}$ Seminar of the International Association for 'Tibetan Studies, St. Hugh's College, Oxford, $612^{\text {th }}$ Septenber 2003.

24 On the history of the monastery of. Panglung (1983: 281-84).

25 The position of the former clay sculptures in what is arguably the oldest structure in the complex the structure on which the Dorje Chenmo temple was built - compares best to those of the Tholing Gyatsa (Luczanits 1996b), which would make one assume that the sculptures were added in the $13^{\text {th }}$ century to an already existing structure. In contrast to the Cryatsa, no older paint layer is evident within the monument and the layout of the temple compares best to the Tabo Assembly Hall, which was built in the late $10^{\text {ih }}$ century. 
walls, the central Jina, seated on a more elaborate throne base, is flanked by four attendant Bodhisattvas with a further two goddesses above and two gatekeepers below (Fig.7). ${ }^{26}$

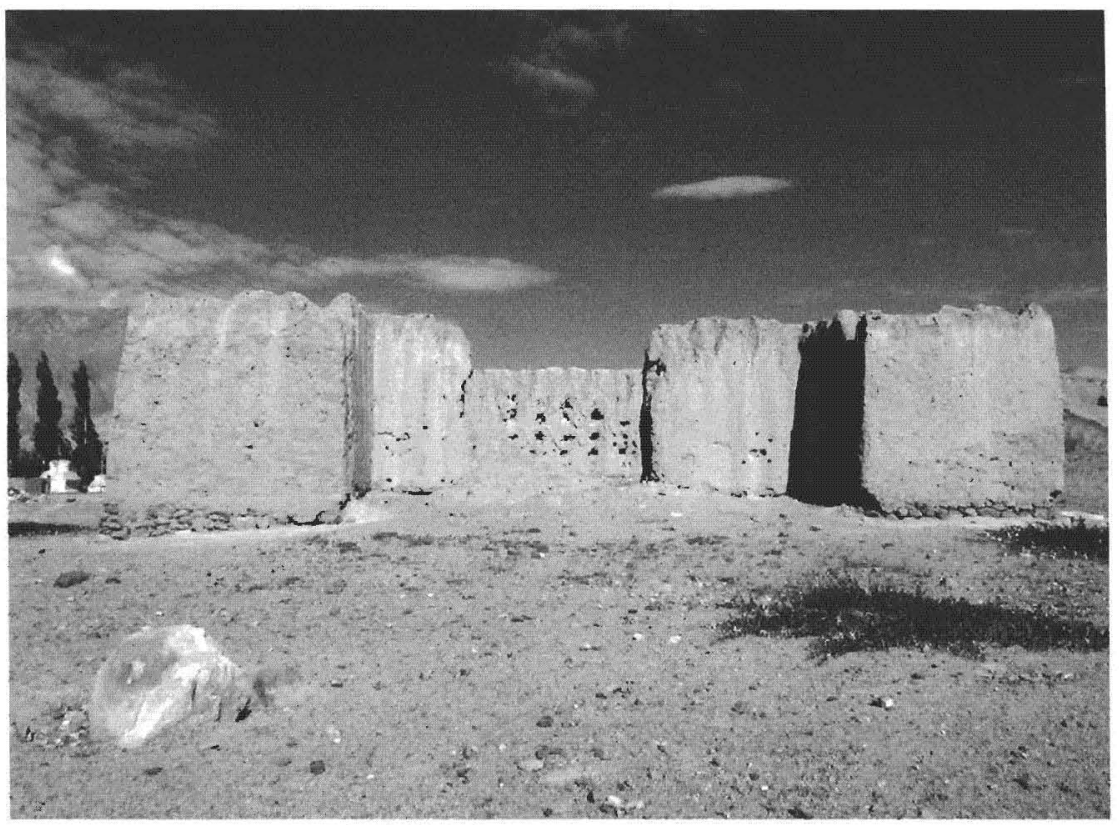

Figure 5. The temple ruin at Basgo with the remnants of clay sculptures clearly visible on the back wall (Photo: C. Iuczanits 2003, DSCN9091).

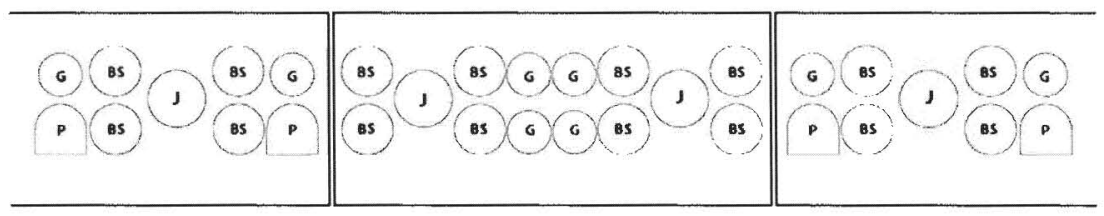

Figure 6. Schematic drawing of the distribution of the Vajradhātu deities in the Basgo ruin. $J$ stands for Jina, BS for Bodhisattva, $G$ for goddess and $P$ for protector/gatekeeper (Drawing C. Luczanits).

Further, the full modelling of the circular halos and their relationship to the pegs that once held the figures compares best to the mid-11th century sculptures of the Tabo Assembly Hall. The upper peg holding the image is placed in the centre of the halo, and the lower peg just at its bottom edge. Below that, two separate pegs once held the lotuses of

26 The complete documentation of the Basgo ruin is found on the website: http://univic.ac.at/ITBA. 
the secondary images. In the case of the Jinas, six pegs in two parallel rows of three held a more elaborate throne that included their vehicles. These factors alone, and their comparison to the constructions found at other western Himalayan sites such as Tabo, Nako, Lalung and the Alchi group of monuments, make it possible to attribute this temple ruin to the middle or second half of the $11^{\text {th }}$ century. ${ }^{27}$

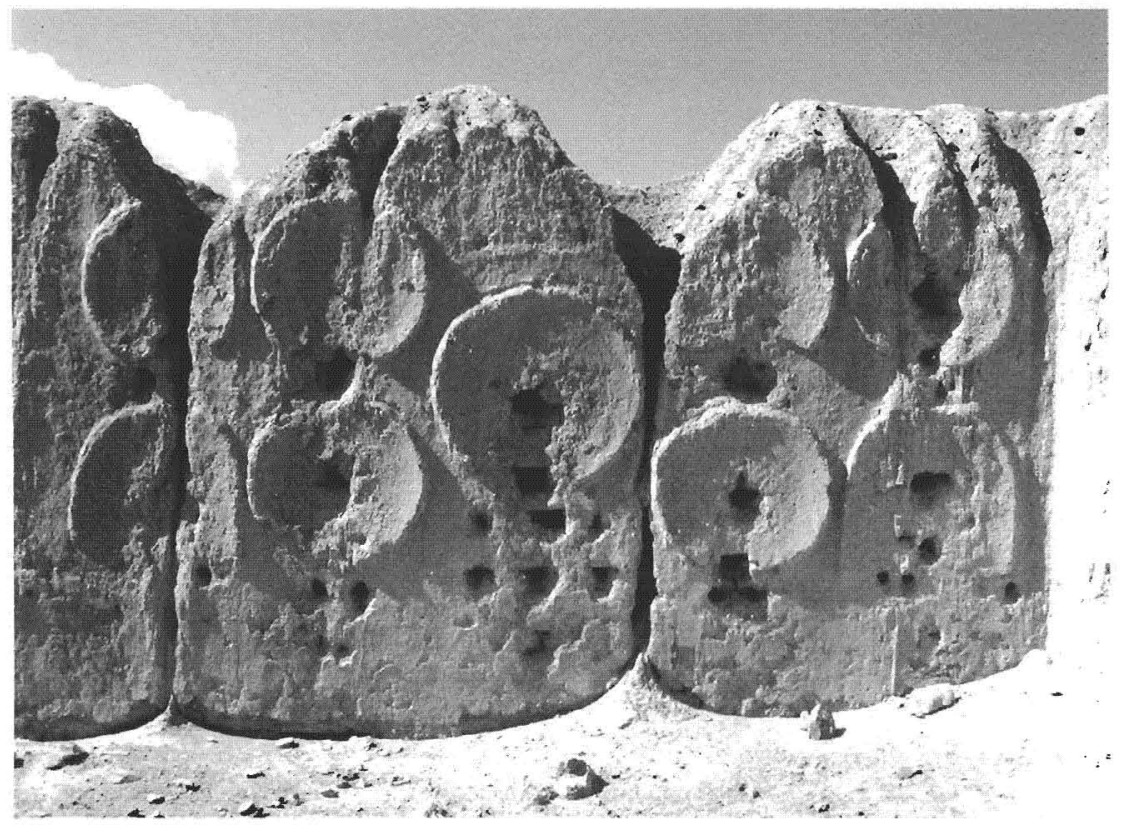

Figure 7: Left sidewall of the Basgo ruin with the halos of nine deities of a Vajradhātumaṇulala: a Jina, surrounded by four vajra-Bodhisattvas and flanked by two goddesses (above) and two gate-keepers (Photo: C. Luczanits 2003, DSCN9087).

While Nyarma has already received some scholarly attention, the numerous other ruins have not been reconsidered since the time of Francke. ${ }^{28}$ Further, all work done so far is simply based on observations of what is apparent from the ruins without any

27 The clay sculptures of the mentioned sites and their historical context are discussed in detail in Luczanits 2004. 'The conclusion suggested here is based on the material collected in this book.

28 Francke not only collected all the epigraphic evidence, but also systematically recorded temple and castle ruins. Some of these photographs, which Francke sent to J.Ph.Vogel in the course of their scholarly discussions, are in the photographic collection of the Kern Institute in Leiden, Netherlands. 
excavation. A comprehensive recording and documentation of the ruins, along with a detailed recording of technical details such as brick sizes and wall construction, would enable us to extrapolate a history of these structures, and make it possible to estimate the extent of early Buddhism in the area. Ideally, these observations need to be supplemented by selected excavations according to modern standards at some of the sites.

\section{Painted Alchi}

Besides the ruins discussed, there are numerous monasteries, temples and chörten in Ladakh which local tradition and relatively recent historical texts describe as foundations of the famous translator Rinchen Zangpo (Rin-chen-bzang-po, 958-1055). However, neither architectural or art historical evidence supports any of these attributions.

For Alchi, already Snellgrove \& Skorupski cautiously refuted this association on the basis of the data available to them (cf. note 2). As already mentioned, Roger Goepper was then able to attribute the Alchi Sumtsek (gSum-brtsegs) to $1200-1220$ at the earliest. This date is based on an inscribed lineage of the Drigungpa ('Bri-gung-pa) school painted on the entrance wall of the lantern or third floor (Goepper 1990; Goepper \& Poncar 1996:211-17). The founder of the 'Bri-gung-pa school (i.e. 'Jig-rten-mgon-po, 1143-1217) is the last person depicted and identified in this lineage, and this points to the completion of the temple in the early 13 th century. ${ }^{29}$ Other evidence within the monastic complex now supports the early $13^{\text {th }}$ century attribution for the Alchi Sumtsek and thus a significantly later chronology for the oldest temples preserved in Alchi and the closely related monuments in Mangyu and Sumda. This evidence also sheds new light on the relevance of the art of Alchi to the development of Tibetan art in general.

The monastic complex (chos-'khor) of Alchi contains some of the most fascinating Buddhist monuments in the Himalayas. In total it

29 One may dispute here whether the presence of the last person in the lineage means that he was still alive at the time of depiction, or if it is a posthumous representation. With Central Tibetan portraits it is often assumed that the depiction is posthumous, but in these cases an additional teacher, often the practitioner (sädhaka) of the respective teaching, is also depicted. Further, such portraits could also be part of a series. In the case of Alchi, I would assume that the depiction fell towards the end of the life of Drigungpa, as the donor and founder of the temple, Tshul-khrims-'od, initiated the depiction. 
contains six temples as well as three painted gateway stupas (Kakani chörten, ka-ka-ni mchod-rten) of a type unique to the Alchi group. Here I focus on recent research on the two oldest and largest temples - the Assembly Hall or Dukhang ('Du-khang) and the Three-Storeyed Temple or Sumtsek - as well as on some paintings of the two oldest gateway stupas within the complex, which I term Great Chörten and Small Chörten (Fig.8). These buildings are attributable to the period dating from approximately the middle of the $12^{\text {th }}$ century to the early $13^{\text {th }}$ century. As is apparent from the inscriptions at Alchi, these monuments were built when an elite of Central Tibetan descent, the Dro ('Bro) clan, ruled a rather small principality in Lower Ladakh. ${ }^{30}$

Before presenting other evidence supporting Goepper's conclusions, the lineage representation on the third floor of the Sumtsek needs to be reviewed briefly. ${ }^{31}$ I have already noted in a previous article (Luczanits 1998) that the depiction of a teacher's lineage was a new subject in western Himalayan art. An analysis of the depiction in comparison to the teacher representations in the Great and Small Chörtens leads to the conclusion that the Alchi lineage was painted in the absence of a proper visual model for their depiction. The representation of the cape may have posed a particular problem for the Sumtsek painters, as the hands performing the various gestures were not meant to be covered.

These uncertainties are no longer apparent in the depictions of the Central Tibetan teacher in the two chörten erected within the monastic complex of Alchi, the well known Great Chörten ${ }^{32}$ and the Small Chörten. ${ }^{33}$ Both contain an inner chörten with its interior walls dedicated to the same four teachers but, while in the Great Chörten only the teachers are shown, in the Small Chörten they are accompanied by secondary figures as well. Of these, only the representation of the Central Tibetan teacher, traditionally identified as Rinchen Zangpo, is of relevance in this context (cf. Snellgrove \& Skorupski 1977: pl.xiii; Goepper 1993: Fig. 14; Luczanits 2003a: Figs.3,4; Luczanits 2004: Fig.218). This figure demonstrates that by now the

30 See the historical introductions in Goepper \& Poncar (1996) or Luczanits (2004).

31 A more detailed analysis of this depiction is found in Luczanits (2003a). For overviews and large-size pictures cf. Goepper (1990), Goepper \& Poncar (1996:212, $216,217)$ and Luczanits (2003a).

32 Cf. Snellgrove \& Skorupski $(1977: 77 \cdots 78)$ and the detailed study by Goepper (1993).

33 Only Snellgrove \& Skorupski (1977:78) describe this important chörten and also note that here the teachers represented in the inner chorten have a context. 
painters had become familiar with the way a teacher is shown in contemporary Central Tibetan painting. ${ }^{34}$

The new artistic influence on the early $13^{\text {th }}$ century monuments at Alchi is even more obvious when one considers the context in which the so-called Rinchen Zangpo is shown in the extremely informative Small Chörten (Snellgrove \& Skorupski 1977: pl. xiii). The teacher is flanked by two standing Bodhisattvas (Avalokiteśvara and Mañjuśrī) and two seated deities at the level of his head (Șadakșaralokeśvara and Green Tāāà). Above these, another unusual lineage of the Kagyüpa (bKa'-brgyud-pa) school is depicted, and to the sides are nine more siddha, while seven protective deities occupy the bottom of the composition. Both the elements comprising this arrangement, as well as their arrangement, are clearly reminiscent of Central Tibetan thangka paintings of that time, although it is executed without the strict divisions that are characteristic of the latter paintings..$^{35}$

In fact, compositions containing all these elements were developed in Central Tibet at approximately the same time, the painting in the Small Chörten being among the earliest representations. The most characteristic elements of this composition are the representation of the teacher as (equal to) a Buddha ${ }^{36}$ and the teaching lineage testifying

34 For the usual depiction of Central Tibetan teachers in early Tibetan paintings cf. e.g. Kossak and Singer (1998: Nos.5,11,17,18,19,26,30,51).

35 In the meantime, an identification for almost all deities and siddha in this composition can be suggested on the basis of a small group of comparable Central Tibetan thangkas of the Drigungpa school, two of them with inscriptions that leave no doubt about the school affiliation. Relevant paintings known to me so far are: a footprint thangka at the Rubin Museum of Art (Himalayan Art 2004: no.65205); another footprint thangka that is chronologically two generations later KlimburgSalter 1982: pl.111); a thangka of the Pritzker collection (Kossak and Singer 1998: no.17); one in a Swiss private collection (Pal 2003mo. 132; and a thangka in poor condition in the Koelz collection at the Museum of Anthropology at Ann Arbor, Michigan (Copeland 1980:98). A detailed analysis of this group of paintings in comparison to the Alchi depiction is in preparation.

36 "Such a painting would certainly seem to pay Rin-chen bzang-po full honours as an acknowledged Buddha-manifestation." (Snellgrove \& Skorupski 1977:78). Teacher representations flanked by standing Bodhisattvas are fairly rare in comparison; e.g. of the ones in Sacred Visions referred to in note 34 only no. 17 the one belonging to the group identified in note 35 - has flanking Bodhisattvas. Other examples with flanking Bodhisattvas, besides the thangkas mentioned in the previous note, are two paintings of the Taglung school: one in the Musce Guimet (MA 6083: Béguin 1995:482 84; Singer 1997: Fig.43, identifies the main image as Onpo L_ama (Sangs-rgyas dBon Grass-pa-dpal 1251 1296) and the others in private collections (Rossi and Rossi 1994: no. 10; Singer 1997: Fig.41, again identified as Onpo Lama). 
to the Indian origin of the teaching. ${ }^{37}$ The systematic emphasis on the Indian derivation of a teaching by means of a teacher's lineage appears to have become prominent in Tibet only during the $12^{\text {th }}$ century within the new schools, and became extremely influential. ${ }^{38}$ The perception of the contemporary Tibetan teacher as (equal to) a Buddha appears to have been established only in the second half of the $12^{\text {th }}$ century in Central Tibet and mainly in a Kagyüpa context. ${ }^{39}$ One may even conclude that the painting in the Small Chörten of Alchi documents the emergence of a new understanding of the teacher in Tibetan Buddhism, certainly within the Kagyüpa schools, and that it was produced on the threshold of a new development of Tibetan Buddhism in general. ${ }^{40}$

The relationship of the Small Chörten teacher depiction to Central Tibetan paintings of the Drigungpa school invariably referring to the founder of the school would make it possible to identify this teacher with Drigungpa himself. ${ }^{41}$ For the time being, I hesitate to do so because of the siddha depicted just opposite the teacher. This siddha is invariably depicted squatting with a meditation band, and holds a twig in his raised right hand and a flute in the left. Just opposite the Central Tibetan teacher, and shown frontally, he must be considered his teacher. He is therefore the crucial figure for deciphering the religious history of the early $13^{\text {th }}$ century monuments of Alchi. ${ }^{42}$

37 The local teachers on the side walls of the Small Chörten, instead of being depicted as a Buddha himself, are surrounded by the five tathaggata headed by Vairocana, while underneath them a row of further local monastic figures is shown (Luczanits 2003a: Fig.5).

38 Whatever tbc social and political circumstances which supported such a move, the need to justify a teaching by its link to the Indian tradition, thus demonstrating its authoritative derivation, is evidenced by the prominent position given to the lineage in the literature and painting of that time.

39 The evidence in this regard is summarised in Luczanits (2003a), Example 1.

40 This development can also be seen as preconditioning the establishment of the first reincarnation lineage after the second Karmapa (Kar-ma-pa) Karma Pakshi (Karma pak-shi; 1204-83) in the course of the $13^{\text {th }}$ century (cf. the fascinating account in Kapstein (2000: in particular 97 100).

41 Amy Heller suggested this identification in a personal communication to me on 10 November 2002 on the basis of the thangka published by P. Pal mentioned in notc 35 , for which she read the fragmentary inscription on the back.

42 For depictions of this siddha-usually identified with Nāropa in the two chörten cf. Goepper (1993: Figs.12,13) and Luczanits (2004: Fig.219). This siddha, is also represented in a prominent position at the bottom of the dhot of Bodhisattva Mañjuśri in the Alchi Sumtsek (Goepper and Poncar 1996:102,109) and is also depicted in the niche of the Assembly Hall of Sumda Chung. 
The depiction of Mahasiddha as they accompany the Central Tibetan teacher is a topic new to the western Himalayas. Even more significant, the representation of the group of 84 such siddha on the dhoti of Mañjuśri in the Alchi Sumtsek is the earliest representation of this topic so far known. As Rob Linrothe (2001) has shown, in this case only a few of the depictions are individualised while generic types abound.

Davidson (2002:303-9) has pointed out that lineages or groups of siddha only become prominent in Tibet in the course of the $12^{\text {th }}$ century. The archetypical lives of a group of 84 Mahasiddha as found in the Grub-thob brgyad-cu-rtsa-bzhi' i lo-rgyus narrated by a certain Abhayadattaśrī were translated into Tibetan by sMon-grub-shes-rab, no secure dates being known for either of them. The number 84 is rather symbolic and the names and the numbers of siddha mentioned in different texts and commentaries vary.

Besides these observations, Goepper (2003) has collected further support for his dating of the Sumtsek and the Kashmiri derivation of its painters. Among them is a certain iconographical emphasis on the goddess Tāra to be observed in the murals. Of the many representations of this goddess, the one in the centre of the left wall of the second storey takes the most prominent position. It shows a standing Tārā as Saviour from Eight Kinds of Fear, flanked by scenes actually showing the dangers or fears and the salvation from them (Goepper \& Poncar 1996:158-163). According to Goepper, this predilection for the goddess may be interpreted as a reflection of the revival of her cult in Kashmir. When Śākyaśrībhadra (1140s-1225) after his return from Tibet reorganised the decaying Buddhist religion and ritual in Kashmir, he promoted especially the cult of Avalokiteśvara and Tārā (Naudou 1980:246-49).

Another Kashmiri priest named Tathāgatabhadra was active in China during the $13^{\text {th }}$ century and translated a sādhana on Tārā as Saviouress from the Eight Kinds of Fear, originally composed by the Kashmiri Sarvajñamitra (late $8^{\text {th }}$ century; Naudou 1980:252). Indeed, as Eva Allinger (1999) has shown, it is Sarvajñāmitra's description of the Saviouress from the Eight Kinds of Fear that is closest to the representation of this subject in the first floor of the Sumtsek as it is the only text that describes different manifestations of Tārā rescuing from the dangers. One may need to add here that Târa is not depicted in

1 Around 1100 appears to be the earliest possible date for the translation, but Davidson appears to favour a $12^{\text {th }}$ century date. 
the Tabo Main Temple at all and in western Himalayan art only becomes more prominently depicted in the $12^{\text {th }}$ century monuments (cf. Luczanits 2004:216).

\section{Alchi rebuilt}

Although Alchi is certainly the most studied and best known monument of Ladakh, many aspects of it have not yet been looked into. This may be demonstrated by summarising one of the findings of recent research visits to Alchi monastery in co-operation with architects of the University of Technology in Graz, Austria. ${ }^{2}$ A detailed survey of the buildings and their artistic decoration makes it possible to extract a more complex picture of the earliest development of the monastic complex, in particular the area in front of the Assembly Hall or Dukhang (Du-khang, Fig.8).

This monument is certainly the oldest preserved of the Alchi group, but there is no decisive clue for the time that elapsed between its construction and that of the Sumtsek. While the sculptural configuration centred on Vairocana in the apse at the back of the temple and the murals appear rather close in style, other forms of decoration indicate a considerable interval in timing. Most remarkable in this regard are the extensive carvings of the doorframe (Francke 1914: pl.xxxix,a) as well as the remaining parts of the veranda, the sides of which are closed up today.

In addition to the veranda, the area in front of the Dukhang testifies to a long history of alterations (Fig.8). As the on-site survey with the Graz architects has revealed, these alterations include the addition of flanking buildings and the courtyard in a relatively clear chronological sequence. First, two tower-like structures were added to the sides of the veranda, of which only the left one is preserved in original proportions. This curious structure has not been decorated at the bottom but contains a painted upper chamber, ${ }^{3}$ While the main wall of this chamber remains undecorated, the side- and entrance walls are covered with paintings. These murals, executed in a rather dark colour palette with shades of brown and yellow dominating, and thus considerably different from that of the other Alchi temples, are today in a deplorable condition. However, stylistically they certainly go back to the early period.

${ }^{2}$ The research visits to Alchi and Wanla were particularly rewarding due to the interdisciplinary composition of the research team visiting the sites.

3 The chamber is used as a storage room today. 


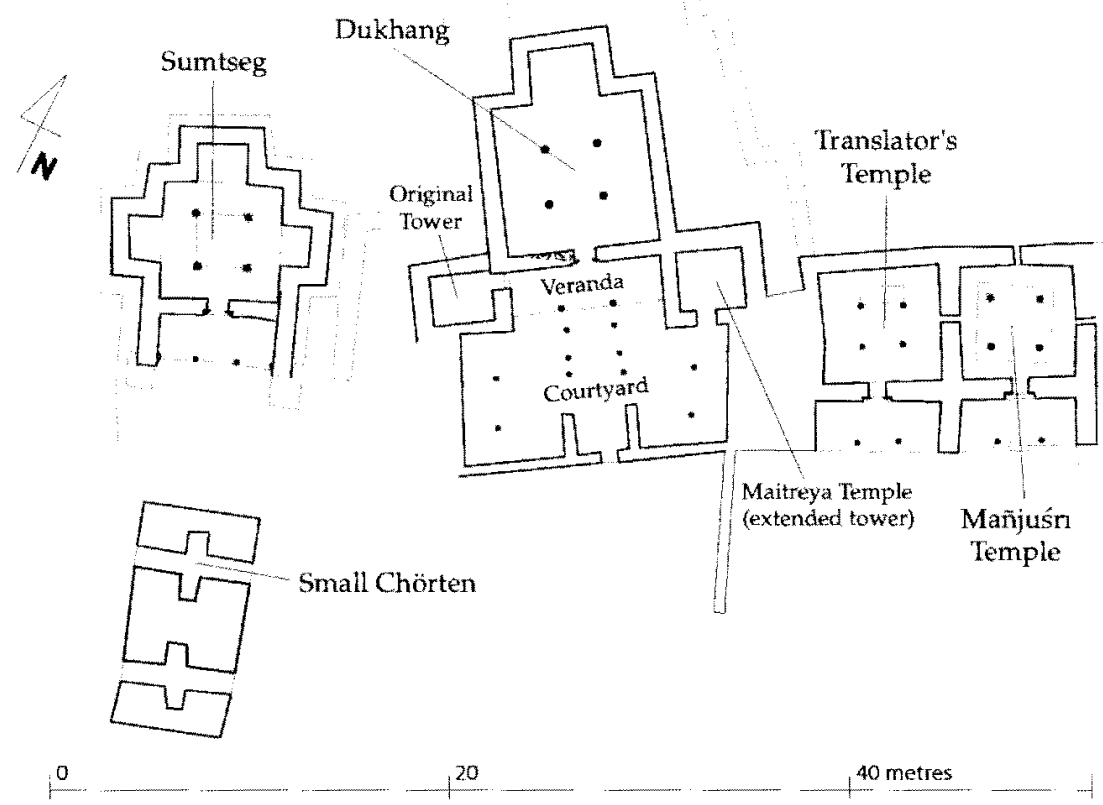

Figure 8: Central structures of the monastic complex at Alchi with the Dukhang and its courtyard in the centre (detail of a plan made by a team from the Graz University of Technology with adjustments by the author).

What could have been the function of this room? The undecorated main wall retains several horizontal rows of holes once containing pegs supporting something, possibly a bookshelf. It is thus quite likely that the structure was added to the Assembly Hall to house the Kanjur or words of the Buddha, or rather that part of it that was assembled at that time. This theory is also supported by the fact that the murals are almost exclusively dedicated to teaching Buddhas and their assemblies.

At a third stage the courtyard was added in front of the Dukhang and the tower-like structures. This is evident from the relationship of the courtyard murals to the architecture. The murals depict mainlyso far unidentified-narrative scenes, which today are largely repainted following the original. Stylistically and iconographically, they are closer to the Sumtsek paintings than to those of the Dukhang. Also, the entrance as it is preserved today was part of the courtyard extension, as is shown for example by the -again repainted-murals of the Wheel of Life. Instead of representing the twelve-fold chain of Dependent Origination, usually represented on the outer circle of the 
wheel, it shows the stream in which beings float after death until they are reborn in one of the six realms. ${ }^{4}$

On the other side of the courtyard, the relationship of the murals to the tower shows that the tower today housing a recent image of Bodhisattva Maitreya, has been extended beyond its original size at a later stage. In the course of the $13^{\text {th }}$ century, a chörten was placed in an unusual manner on pillars in the middle of the courtyard. This structure is certainly simpler in shape and in its decoration than the two earlier chörten discussed above but, like them, it contains a smaller chörten placed inside the chamber of the larger one. However, its paintings are stylistically completely different from those discussed until now as they clearly derive from Central Tibetan painting.

This is just one of the results of the detailed interdisciplinary survey undertaken in recent years in the monastic complex of Alchi. Once all information collected in this survey has been analysed in comparison to other relevant sites such as Mangyu, Sumda and Wanla, the history of the monastic complex and its interrelationship with other monuments will appear in a new light. ${ }^{5}$

\section{The rood carings of Alchi in context}

It is well known that the early Alchi monuments have rich wooden decoration, with lion brackets, capitals, pillars and basements in the interior and more or less elaborate carvings in the verandas in the front of each temple. The Alchi Dukhang also preserves a richly carved doorframe, the only one that appears to be preserved today in Ladakh, with sets of deities and scenes of the life of the Buddha carved on them. ${ }^{6}$ This door, to be attributed to the mid-12th century at the earliest, certainly had its predecessors, among them the façade of the Chigtan temple documented by A.H. Francke (1914: pl.xliii,b), and the fragments of a door in a temple at Lhachuse, near Kanji.

The wooden fragments of Lhachuse are the only remnants of what must once have been an extremely impressive temple. Inside the temple, huge capitals and bascments made of a single piece have

4 Comparable depictions of the Wheel of Life are known from the Tabo Entry Hall, where only fragments are left (Klimburg-Salter 1997), and a cave in Phyang, north of Tholing in West Tibet (Neumann 2002).

${ }^{5}$ A detailed chronology of the temples and chorten within the monastic complex in Alchi is in preparation.

${ }^{6}$ E.g. Snellgrove \& Skorupski (1977:pl. 3, Figs. 24, 25). A publication of the Alchi Dukhang door is currently being prepared by Heinrich Poll for the Joumal of the Asiatic Socieby in Mumbai (no. 79). 
partly been reused. The present entrance is made up of sections of what was once a much larger door, again carved with the life of the Buddha and single deities in separate fields (Fig.9). ${ }^{7}$ Further, fragments of the former veranda have been reused for the living rooms of monks built just in front of the entrance to the temple (Fig.10).

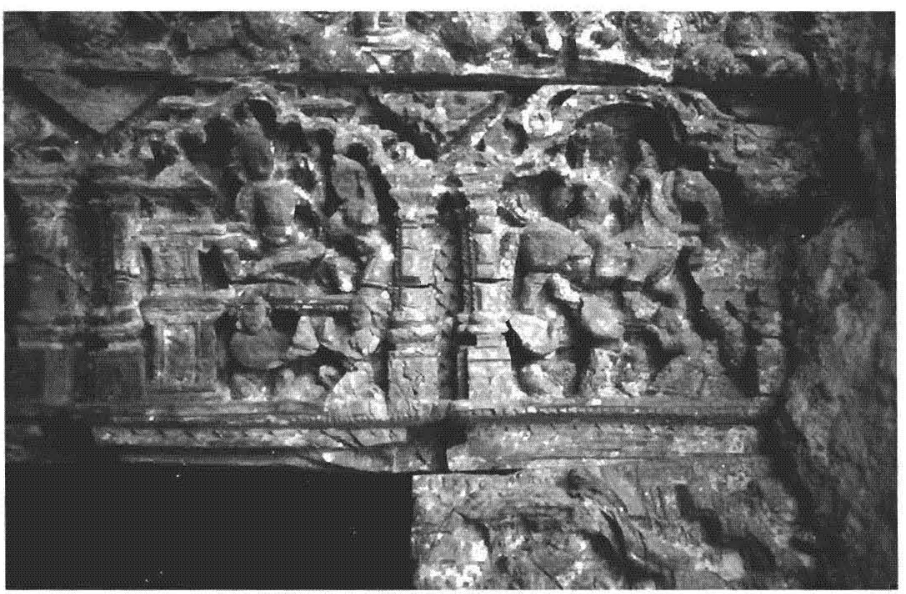

Figure 9: Two scenes of the Life of the Buddha; the Bodhisattva in the palace and the Great Departure (photo: John Harrison 99 9,37; WHAV).

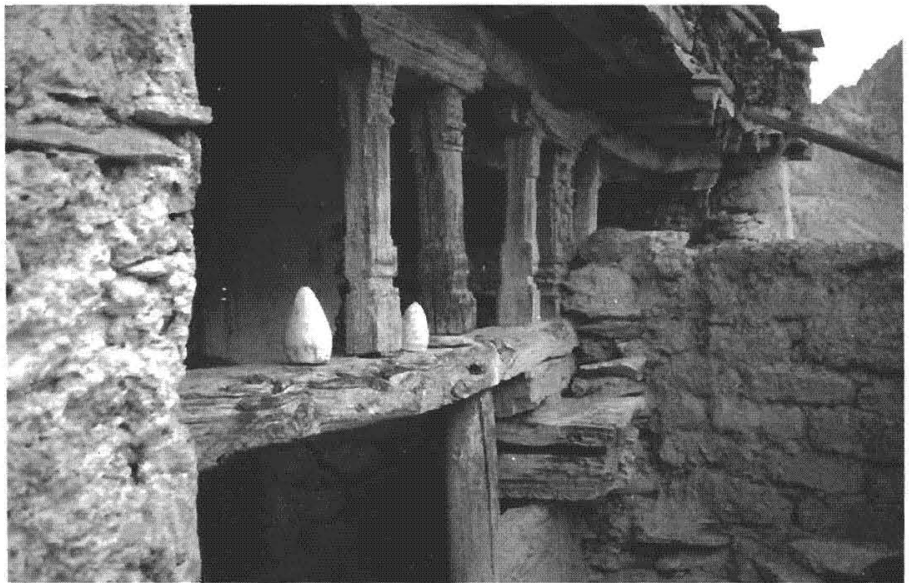

lïgure 10: Fragments of a former veranda construction re-used (Photo: J. Harrison 19999,14 ; WAV).

7 The monuments of Kanji and Lhachuse were first noticed by Vitali (1996). In 1998 a joint team of the Achi Association and the Vicnna research project visited and documented the place for the Vienna archives. I documented them a year later. 
How such a veranda once looked is clear from a comparison to the Alchi and Wanla temples. In all these cases, the veranda is tripartite, with the sections defined by pillars supporting the roof or a two-tiered wooden structure in the upper part with small supporting pillars between the two levels. In the case of the Alchi Dukhang and Wanla, ${ }^{8}$ this two-level structure is interrupted in the centre to mark it and the door behind. At the Sumtsek the clerestory is not interrupted and triangular ornaments are placed above all three parts. It would be interesting to study the presumed Kashmiri origin of this type of veranda and the elements comprising it. ${ }^{9}$

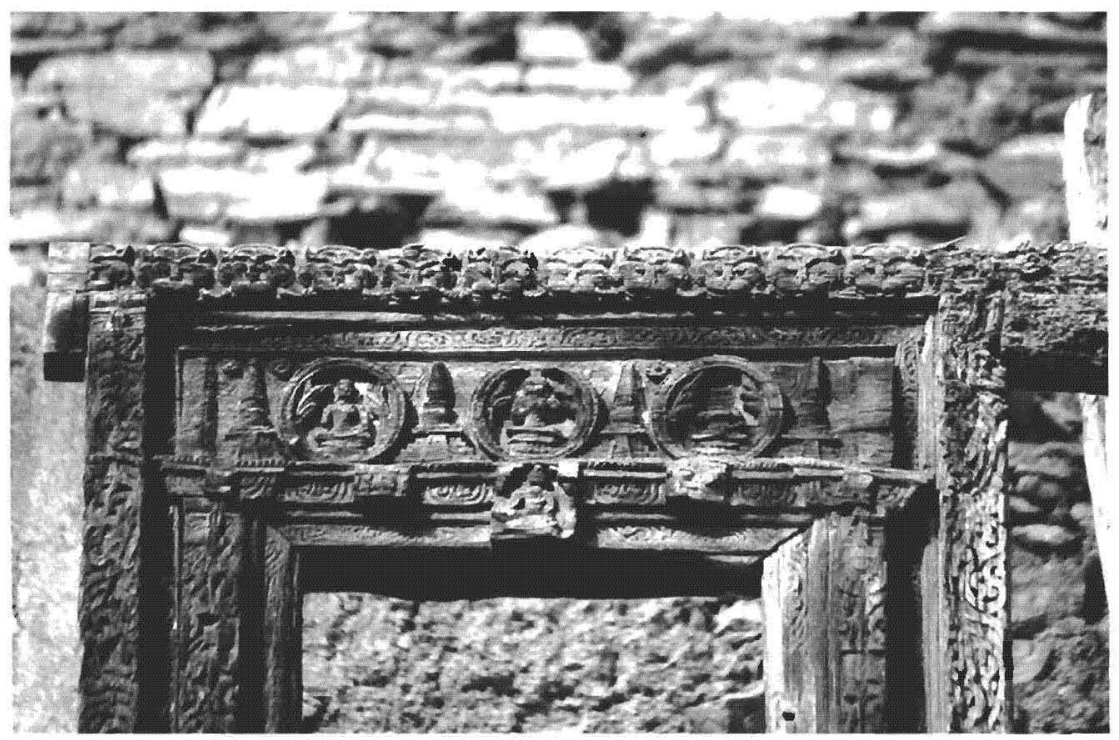

Figure 11: Front lintel of the Sumda door with three Buddhas in medallions flanked by stupas (Photo: C. Luczanits 1998 109,50. WHAV).

It is clear that the Alchi carvings represent a late stage in this woodcarving tradition when one also considers the contemporaneous carvings of Mangyu. Although the small Mangyu temples are structurally built the same way as those at Alchi, the carvings on the doors and the parts of the veranda are much less sophisticated. Sumda, by contrast, may once have had a veranda similar to those at

8 Cf. the construction of the veranda at the temple of Wanla Kozicz 2002; Luczanits 2002).

9 The doors of Ribba, Kojarnath (cf. Luczanits 1996a) and Tholing (cf. KlimburgSalter 1988) also have to be considered in establishing a forerunner for the Ladakh doors. 
Alchi, but almost nothing remains of it since the whole front of the Sumda Assembly Hall collapsed at some point and has been rebuilt. ${ }^{10}$ A temple ruin on the hill below the Sumda Assembly Hall still preserves a beautifully carved doorframe with deity-bearing medallions between stupas (Figure 11). Remarkably, stupas have been used extensively at Sumda for ornamental purposes (cf. Luczanits 2004:175-90, 246-47). Further, the extensive but less sophisticated carvings of the Wanla temple clearly refer back to earlier examples, as predecessors for almost all details can be found at Alchi.

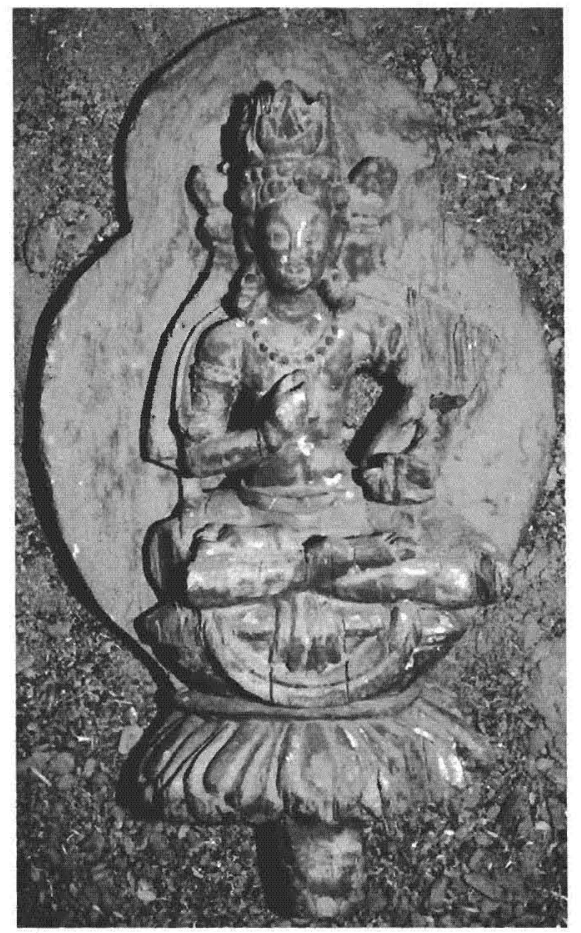

Figure 12: The image of a Bodhisattva carved in wood from the forgotien depot in Alchi monastery (photo: CL98 99,42; WHAV).

Alchi and related monuments also preserve a number of now independent wooden images that must be seen as products of a widespread tradition that Ladakh shares with the regions of Lahul and Kinnaur." Snellgrove \& Skorupski (1977: Fig.26; 1980: Figs.20,24)

${ }^{10}$ As can be seen from the architecture and decoration of the temple, the collapse included the front walls of the main temple and the two side chapels (Luczanits 2004).

11 The smaller images could once have been part of the veranda as evidenced by 
published some of the Ladakhi wooden images and stupas in Sumda Chung, where at least some of them are still to be found in the apse. Attempted and successful thefts and sales of such images have resulted in their being hidden away along with bronzes in locked up parts of the temples and/or cabinets, and this has so far made it impossible to document and study them. In the case of Alchi, such images are so well hidden that even the caretakers of the monastery do not know about them any more (Fig. 12).12 These images are of different ages but many appear to retain an old style peculiar to the earliest monuments, possibly copying and replacing earlier images.

The only wooden image that has received wide attention is the wooden sculpture of a two-armed Maitreya in the temple ruin of Sumda Chen. This image, in a rather crude and comparatively flat style has been attributed to the $8^{\text {th }}$ century on the basis of a Carbon 14 dating of the wood (Vohra 1993). I recently learned, however, that this attribution is based on a misinterpretation of the $\mathrm{Cl} 4$ result by the author, who took the measured result as the $\mathrm{AD}$ date. ${ }^{13}$ In fact, the $\mathrm{Cl} 4$ analysis dates the wooden fragment taken from the image to 760 $+/-155$ years prior to 1950 , i.e. the period from $1035-1345.14$

the images set into the triangular spaces of the Sumtsek veranda. On the early wood carvings of Kinnaur and West Tibet cf. Luczanits (1996a).

12 We discovered a depot of fragmented wooden images in Alchi itself while doing research therc. This depot was not known to the caretaker.

13 The mistake in Vohra's interpretation was pointed out to me recently by Heinrich Poll (e-mail of 29th August 2004), who noticed that the quoted result in Vohra's article contradicts his interpretation. Vohra took the measurement result the years before BP) as being the date of the fragment itself. He presents the following results:

Sample No. PRI-1430; Site: Ladakh Wood Sample; C14 Date (uncorrectcd) Counted in Iiquid Scintillation System; Half Life 5568 Yr: 740+/-150 Yr BP; Half Life -5730 Yr: $760+/-155$ Yr BP, whereby the latter measurement is considered somehow more accurate.

Vohra quotes - he crroncously gives the year $1989 / 90$ instead of $1990 / 91$ - a report of the Archaeological Survey of India, who undertook the measurement which only gives the result of the latter measurement in the form of the years before present, stating that present is to be taken as prior to 1950 (Mahapatra 1995:97, 99).

14 In an earlier version of this paper, before Vohra's mistake was brought to my attention, I had expressed my suspicions regarding $\mathrm{C} 14$ dates of wood in general terms: "One may express a word of caution in this regard, as what is dated by this method is the time when the respective rings in the tree used for the sculpcure grew, and not when the image itsclf was carved. The sample for testing may have been taken from the core and the tree may have reached an age of 200 years before it was cit, making a carved piece using core wood 200 years younger than its Cil4. Further, it is quite possible that a wooden object is caned out of an older beam." 
Remarkably, there are a number of other images at the same locality, placed along the remaining wall of the former temple. These images have the bizarre beauty of weathered wood: they are of a different, more sophisticated style, and are also rather flat. While many of these fragmentary images do not permit a conclusion regarding their cultural context, the sculpture of the Jina Amoghasiddhi (Fig. 13) may be compared to the latest clay sculptures of the Alchi group of monuments. Particularly characteristic for this phase is that the vehicle, in this case a pair of garuda, is represented on top of the lotus with the image sitting cross-legged above it. Incidentally, this comparison suggests an attribution of these images conforming to the range of the C14 sample mentioned above.

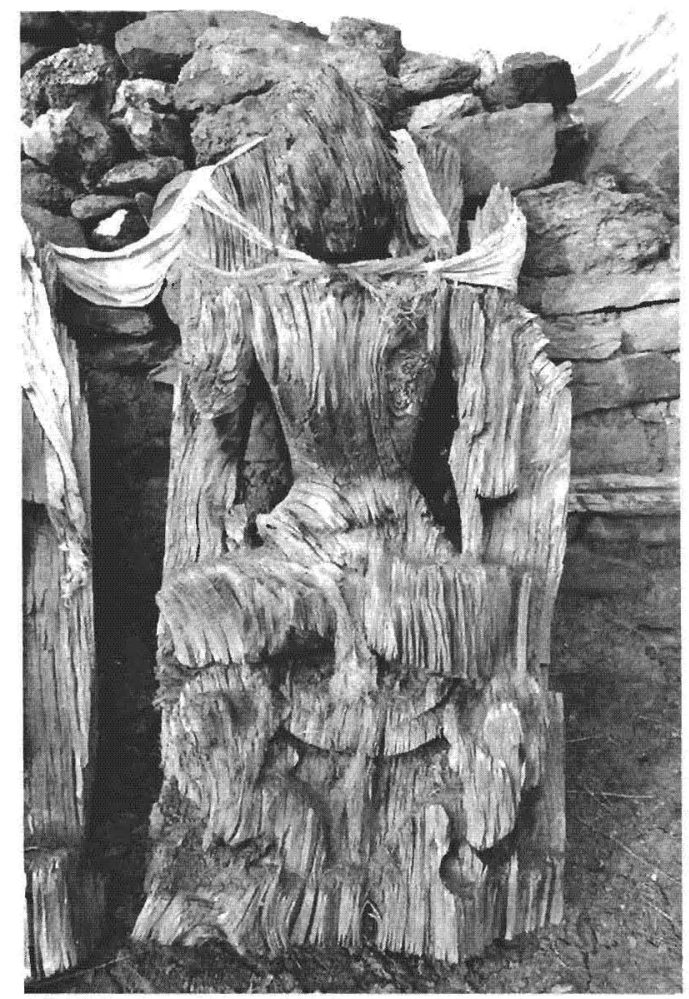

Figure 13. Sculpture of Jina Amoghasiddhi at Sumda Chen

It can be assumed that these woodcarvings are the remnants of once numerous carvings found throughout Ladakh and particularly in the Kargil region, which is much closer to the sources of wood. It would not be surprising if fragments of former wooden verandas and interior 
decoration are still to be found reused in mosques, temples or private houses at places like Chigtan or Mulbek. These carvings are an extremely important aspect of the cultural heritage of Ladakh that is largely underestimated. Unfortunately, many of them, even when superstition does not come into play as in the case of the Sumda Chen sculptures, are exposed to weather and wither away year by year. ${ }^{15}$

\section{The Alshi group}

Decorated by artists of the same cultural background as the early Alchi monuments, the oldest temples of Mangyu and Sumda are equally important. In fact, although in principle representing the same cultural heritage, each of these places preserves unique features, and until now it has only been possible to establish the same workmanship for a small group of temples at these sites. ${ }^{16}$ However, it still remains to compare the murals of the sites in sufficient detail to establish their succession and interrelationship, and to differentiate between workshops. ${ }^{17}$ Roughly, the three sites can be considered contemporaneous with most temples and chapels built around 1200. As additional ruins at Sumda Chung and Sumda Chen show (see below), the preserved monuments represent just a part of the temples erected during the Alchi kingdom.

The influence and establishment of the new schools of Tibetan Buddhism, which is first evident in the latest Alchi monuments, resulted in an almost complete replacement of the earlier western Himalayan tradition during the $13^{\text {th }}$ century. Nevertheless, religious change alone is not sufficient to explain why the artistic tradition of the Alchi group of monuments was not continued in any form. As one can see from the Alchi Sumtsek and the two early Alchi chörten, the artists of the Alchi monuments certainly were capable of representing new iconographic themes in a satisfying manner. Thus, it can be assumed that, if this artistic school had still been affordable and/or

15 In 1994 the Sumda doorframe was still part of a ruined structure with the wall above the door preserved. In 1998 the door was freestanding and even more exposed to weather than before.

16 The unique features of Mangyu and Sumda and the case of the same sculptors working on all three sites are elaborated in Luczanits (2004).

17 The Western Himalayan Archives Vienna (WHAV), which presently also contain the documentation of Alchi by Jaroslav Poncar, allow for such a comparison to some extent. However, for a detailed analysis more documentation at Mangyu and Sumda is necessary. 
available to the later founders, they would have availed themselves of it as well.

The replacement was not as sudden as it appears at first sight. When the chronology of the Alchi Group monuments is considered in more detail, it becomes apparent that temples like the Mañjuśri Temple in Alchi show a decline in material and artistic quality. Further, the Lotsaba Lhakhang, which was added to the side of the Mañjuśrī temple at some later stage, ${ }^{18}$ combines the earlier western Himalayan stylistic features with the foreign central Tibetan ones. However, the artistic quality of the murals is much poorer than in any of its predecessors.

In addition, there are a number of chörten throughout Ladakh, commonly those associated with Rinchen Zangpo, that may be interpreted as less sophisticated examples of the Alchi painting style. ${ }^{19}$

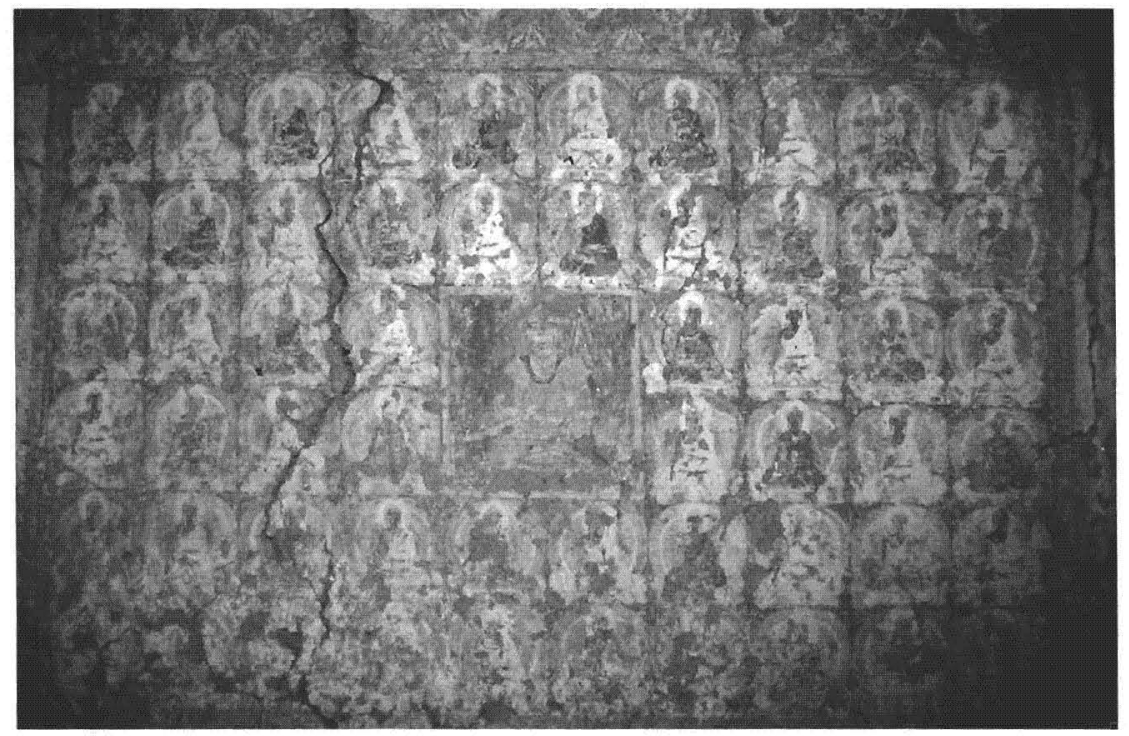

Figure 14: Wall of the Priests' Chörten at Lamayuru with a priest or nobleman in the central panel (Photo: C. Luczanits 1998 58,03; WHAV).

It may suffice herc to demonstrate this by examining one examplc: the painted inner chamber of a chörten that is part of the chörten cluster near the village houses of Lamayuru. This chörten, which I propose to

18 This too is a result of on-site interdisciplinary work with the Graz arehitects.

19 The gateway chörten at Basgo and the ruined chörten in front of it may also be counted among these. 
call the 'Priests' Chörten', is located closer to the cluster than the chörten with the $13^{\text {th }}$ century foreign painting style that I have published elsewhere (Luczanits 1998), and thus presumably precedes it. The painting style of the Priests' Chörten is close to that found in the later monuments of the Alchi group (Fig. 14). Saclly, only two of the painted walls are preserved in poor condition, both covered with repeated representations of Buddha Akșobhya and a small central panel dedicated to a local personality - in one case apparently a monk (Fig. 15) and in the other a priest and/or noble man (Fig. 14)-seated in meditation on a flat throne with geese.

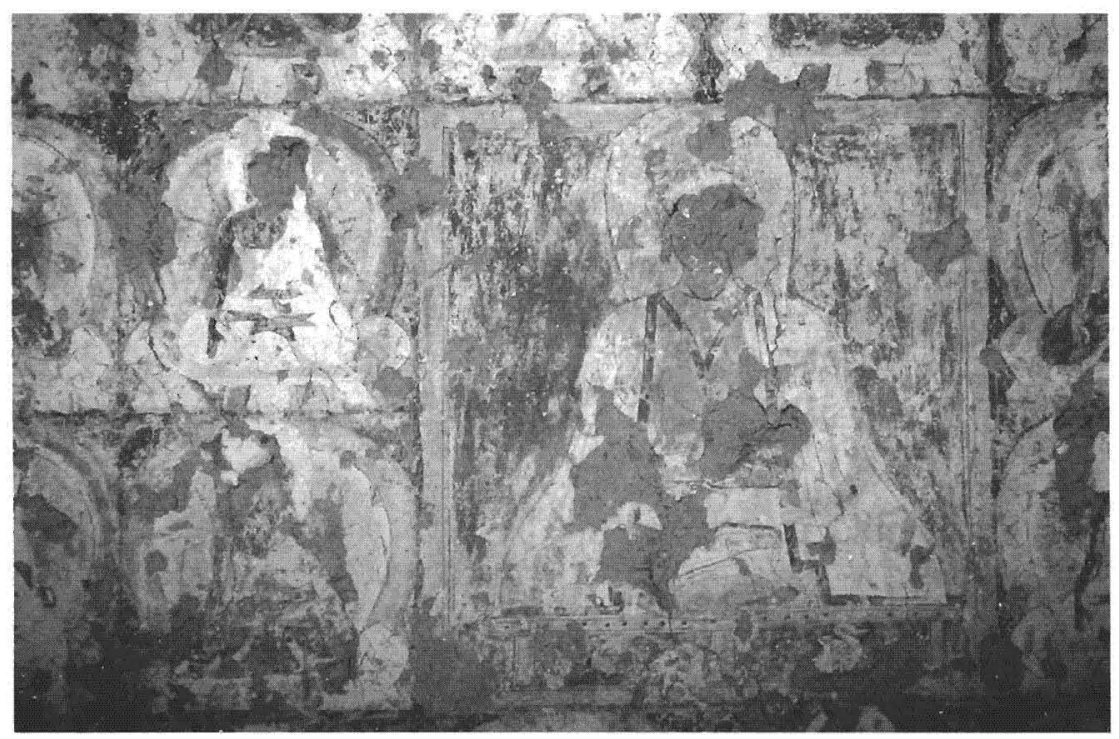

Figure 15: The white haired priest in the other central pancl wears a white cape with a blue rim (Photo: C. Luczanits 1998 58, 18; WHAV).

The priest wears a distinctive hat, a tight-fitting undergarment and a heavy scarf with a blue border that is depicted like the scarf of a monk's habit, all light brown (Fig.14). He also has beautifully ornamented boots and an $\bar{u}$ rna marks him as a great being (mahäpurușa). The meditating monk has short white hair and is dressed in bright garments (Fig.15). A red cloth wrapped around the waist holds the dress, light brown with a black border. The white mantle with a blue rim is furry at the top and has two rows of short coloured and pointed tassels attached to it. He further wears beautifully ornamented whitc boots and possibly large circular earrings. If one compares these depictions to those in Alchi discussed above, one can conclude that 
both the iconography of the Lamayuru chörten in general - as well as the way the priests are depicted-suggest an attribution of the Lamayuru chörten shortly after the Alchi Sumtsek.

\section{Ladakhi painting}

In the course of the $13^{\text {th }}$ century, art influenced by Central Tibet becomes prominent. The second painted chörten in the Lamayuru cluster just mentioned is evidence of foreign painters working in Ladakh during that period (Luczanits 1998), ${ }^{20}$ However, what finally becomes dominant are indigenous versions of Central Tibetaninfluenced painting which were used up to the $16^{\text {th }}$ century, and thus far into the period of the Ladakhi kingdom.

As I have shown in a short article, the Auspicious Three-storeyed Temple at Wanla (that is the name used in the foundation inscription there-bKra-shis-gsum-brtsegs) is probably the earliest of the monuments that can be termed genuinely Ladakhi (Luczanits 2002). According to an inscription to the side of the Maitreya image, the Wanla temple was erected by a certain 'Bhag-dar-skyab, the eldest son of a minister of an unnamed government. This occurred most probably in the late $13^{\text {th }}$ or early $14^{\text {th }}$ century, an otherwise wholly obscure period of Ladakh's history (see Vitali: this volume).

The murals at Wanla also display a marked shift away from earlier iconographic programmes such as those of Alchi. The inscription mentions that all aspects of the Buddhist teachings of the time- 'old and new' - are present in the decoration assembled in the extensive pantheon covering the walls. Indeed, the decoration is characterised by a mixture of deities that had been prominent in earlier western Himalayan monuments and deities deriving from iconographic themes that were 'new' to the region and are characteristic of the Kagyüpa (bKa'-brgyud-pa) schools.

Related painting styles are found in a large number of monuments that can only be listed here. Well known are the Lhakhang Soma (1Hakhang So-ma) at Alchi (for pictures cf. Snellgrove \& Skorupski 1977:64-70, 79, col.pl. xvii, Figs.55-64; Khosla 1979:pl. 41; Klimburg-Salter 1982:165,167, Figs.14,17,26,45; Pal \& Fournier

20 The complete documentation of the two chörten at Lamayuru and another almost ruined chörten at Alchi Shang-rong is found on my research websitc: htt://univieacat/ITBA/. Another relevant chörten, combining two Central Tibetan-derived painting styles with two clay sculptures, is located at Karsha in Zangskar and has been published as Karsha Kadampa Chorten Linrothe and Kerin 2001 . 
1982:62, Figs. LS1-37; and Béguin \& Fournier 1986: Figs.10-14), the Senge Lhakhang (Seng-ge 1Ha-khang) at Lamayuru (Khosla 1979: pl.53; Genoud and Inoue 1982: 'Lamayuru' 1-6) and the Guru Lhakhang at Phyang (Genoud \& Inoue 1982: 'Guru Lha khang'; and Béguin \& Fournier 1986: Figs.19-21). Major monuments of similar styles are those of Alchi Shang-rong (Béguin \& Fournier 1986: Figs.39) and Kanji (Vitali 1996), the latter most closely associ-ated with Wanla. Also the somewhat different painting styles in the cave at Saspol (Snellgrove \& Skorupski 1980: col.pl.iv, Figs.69-73; Genoud and Inoue 1982: 'Saspol'; Béguin \& Fournier 1986: Fig.22) and the temples of the Alchi Tsatsapuri complex need to be considered.

It appears that most of these genuinely Ladakhi monuments were created under some branch of the Kagyüpa schools, most prominently among them the Drigungpa, which still have a strong presence in the area. That the latest of these monuments, the Guru Lhakhang, may date to the 16 th century has already been suggested some time ago by Béguin \& Fournier (1986), and their attribution has recently been supported by Lo Bue. ${ }^{21}$ The other monuments mentioned above still await a more detailed study.

As for Alchi, Wanla and the Guru Lhakhang, the traditional attributions of a temple need to be reviewed in the light of the development of Tibetan Buddhism in general and the specific historical circumstances of Ladakh. Also for other monuments such a review may reveal new information about the social, cultural and religious history of the area that is not preserved in any of the historical sources known so far. In fact, these monuments are the products of small, rather local principalities and/or religious groups with a wide range of cultural, economic and religious links with neighbouring areas.

However, rock carvings, wooden images and monuments are far from being the only heritage that can help us to decipher these international connections. Portable works of art, such as bronzes, thangkas and other objects are certainly also important sources. However, their interpretation and historical value is more difficult to evaluate as they may originally have been produced for a different environment and just happen to be preserved in Ladakh.

21 Lo Bue presented his recent research on the Guru Lhakhang at the $10^{\text {th }}$ Seminar of the International Association for Tibetan Studies, St. Hugh's College, Oxford, 6$12^{\text {th }}$ September 2003. 


\section{Conclusion}

With Ladakh more and more taking on the excessive speed of the socalled 'First World', its cultural heritage is increasingly coming under pressure. Year by year, evidence of the early history of Ladakh gets further distorted or lost due to repair, reconstruction, negligence and/or natural damage. ${ }^{22}$ I think all local and foreign scholars interested in this heritage have their own story to tell in this regard. Modern needs, such as building a more appropriate bridge over the Indus at Kargil, often entail some loss of heritage, such as the damage and loss of some of the rock engravings at this historic bridge site. Detailed surveys and documentation of different aspects of this heritage before something is altered are therefore an extremely important task today for those interested in this heritage and the information it provides.

In this short study I have attempted to provide an overview of the most important remains of early architectural and art historical evidence that can help to improve our knowledge of Ladakh's more distant past, once a sufficiently dense documentation is available for study. ${ }^{23}$ I have stressed the largely ignored aspects of this heritage because a holistic approach, as demonstrated by the work of A.H. Francke, appears out of fashion today. The importance of minor artistic heritage such as rock- and stone-carvings, stone-engravings and wood carvings and ruins of all kinds for evaluating Ladakh's distant past - as has been demonstrated by the pioneering works of Francke, Giuseppe Tucci, David Snellgrove and Tadeusz Skorupski-appears

22 While negligence and natural damage have always taken its toll, the excessive speed of reconstruction and restoration efforts are characteristic of present-day Ladakh. Obviously, there was and still is a need for primary measures to ensure the preservation of a structure, but many of these measures go beyond the primary task of preservation and the rate at which such measures are taken at some monuments is threatening by itself. It is certainly sufficient to recapitulate the works done on Alchi monastery alone in the last three decades, the latest being the cleaning and varnishing work done on the veranda structures. However, the main structural problem to the Alchi monuments, the excessive roof load, has apparently not even been recognised. In the absence of detailed documentation, clues to the original appearance of the structures get lost with each measure. Luckily, with the exception of the exemplary preservation measures taken by the Save Alchi project at the murals of the two oldest chorten and the extremely poor repainting effort by a local artist in a restricted area, the murals of Alchi remained untouched.

23 It cannot be over-emphasised that any study based on art historical methods needs a sufficiently large body of documentation to yield results of value (cf. Luczanits 2001 ; Luczanits 2003a). Work with other scientific methods, such as epigraphy or the study of building techniques, equally profits from a larger body of evidence. 
to be underestimated today. However, only the consideration of the major and minor monuments together with the fragmentary remains will do justice to the fascinating early history of Buddhism in Ladakh, as well as its economic and cultural relationships. Only in this way will we be able to judge the extent and duration of local principalities, their military strength, ${ }^{24}$ their international relations and their cultural and religious affinities.

It needs to be emphasised that the examples in this article focus only on documentation that $I$ have done in the last decade and the available published material. The regions that I have not covered, such as much of the Kargil and Zanskar districts as well as Nubra and the vast area towards the border of West Tibet, will yield additional clues to the early history of the region-particularly if one does not focus solely on well-preserved material. ${ }^{25}$ Further, only very few excavations (the results of which have not been published) and no systematic recordings of any discoveries or losses during construction work and similar enterprises have been done so far (or they are not accessible). An innovative approach, combining an excavation-like scholarly enterprise with the religious needs of the community, has been demonstrated by the documentation and research done on the Karsha chörten by Rob Linrothe and Melissa Kerin (Linrothe and Kerin 2001).

Documentation of Ladakhi monuments and other artistic heritage already exists spread all over the world, but there is no place in Ladakh, where those willing to make their documentation locally available to scholars can deposit a copy of it. ${ }^{26}$ This drastically contrasts with the fact that documenting a monument even for scholarly use has become more and more difficult and in recent years practically impossible. It can only be hoped that the Ladakhis find solutions for both these problems in the near future.

\footnotetext{
24 See the exemplary work on castles and fortresses by N. F. Howard (1989; 1995).

25 See the description of the upper Indus area by Francke (1914:54 ff.).

${ }^{26}$ From different discussions with local scholars it becomes clear that no institution is unanimously accepted as being a possible place for such an enterprise.
} 


\section{Acknowledgements}

I owe the existence of this article to the initiative and patience of John Bray. The study incorporates information generously provided by Amy Heller and Heinrich Pöll in personal communication and some results of fieldwork done in cooperation with architects from the University of Technology in Graz, Austria, headed by Holger Neuwirth. The research results incorporated here have been developed during a three-year research grant of the Austrian Academy of Sciences (APART), which also supported field research in the area in summer 2003. Further, one research trip in spring 1994 was supported by a 'Stipendium für eine kurzfristige wissenschaftliche Arbeit im Ausland' awarded by the University of Vienna, while another in 1998 was privately funded by Edoardo Zentner (Achi Association; www.achiassociation.org). The Austrian Research Funds (FWF) generously supported my research in Ladakh and other regions of the western Himalayas for more than a decade.

\section{REFERENCES}

Allinger, Eva. 1999. "The Green Tara as Saviouress from the Eight Dangers in the Sumtseg at Alchi." Orientations 30, 1:40-44.

Beckwith, Cihristopher I. 1987. The Tibetan Empite in Central Asia: A History of the Singgle for Great Power among Tibetans, Turk, Arabs, and Chinese during the Early Middle Ages. Princeton; Princeton University Press.

Béguin, Gilles. 1995. Les Peintures du Bouddhisme Tíbétain. Paris: Réunion des Musées Nationaux.

Béguin, Gilles, and Lionel Fournier. 1986. "Un Sanctuaire Méconnu de la Région d'Alchi." Oriental Art 32, 4: 373-387.

Gopeland, Carolyn. 1980. Tankas from the Koelz Collection. Vol. 18, Michigan Papers on South and Southeast Asia. Ann Arbor: The University of Michigan.

Davidson, Ronald M. 2002. Indian Esotenc Buddhism: a Social history of the Tantric Movement. New York: Columbia University Press.

Denwood, Philip. 1980. "Temple and Rock Inscriptions of Alchi." In The Cultural Heritage of Ladakh, 2: Zangskar and the Caue Temples of Ladakh. Edited by D. L. Snellgrove and T. Skorupski. Warminster: Aris \& Phillips.

Denwood, Philip T., and Neil F. Howard. 1990. "Inscriptions at Balukhar and Char Zampa and archaeological observations on the fort of Balukhar and its environs." In Indo-Tibetan Studies. Edited by T. Skorupski. Tring: The Institute of Buddhist Studies.

Filigenzi, Anna. 1999. Il Bodhisatta Maitreya nell'arte nupestre delo Suat. Appunti sult'iconografia e sul culto det Buddha venturo. Vol. 13, Conference IsLAO, Roma: Istituto Italiano per l'Africa e l'Oriente. 
Fisher, Robert E. 1989. "Later Stone Sculpture (Ninth-Twelfth Centuries)." Art and Architecture of Ancient Kashmir: 105-116.

Fontein, Jan. 1979. "A Rock Sculpture of Maitreya in the Suru Valley, Ladakh." Aribus Asiae $41,1: 5-8$.

Francke, August Hermann. 1905. "The Rock Inscriptions at Mulbe." Indian Antiquary $35: 72-81$

. 1914/repr. 1992. Antiquities of Indian Tibet, Part 1: Personal Narrative. Vol. 38, Archaeological Survey of India, New Imperial Series. Calcutta/New Delhi: Archaeological Survey of India/ Asian Educational Services.

- 1926 / repr. 1992. Antiquities of Indian Tibet. Part II: The Chronides of Ladakh and Minor Chronicles. Vol. 50, Archacological Survey of India, New Imperial Series. Calcutta/New Delhi: Archaeological Survey of India/Asian Educational Services. Genoud, Charles, and Takao Inoue. 1982. Buddhist Wall-Paintings of Ladakh. Geneve: Olizane.

Goepper, Roger. 1990. "Clues for a Dating of the Three-Storeyed Temple (Sumtsek) in Alchi, Ladakh." Asiatsche Siudin: Zeitschift der Schteizerischen Gesellschaft fuir Asienkude Lihudes Asiatiques: Rou de la Soriété Suisse d'Études Asiatiques 44, 2:159-175. 1993. "The 'Great Stūpa' at Alchi" Artibus Asiae LIII (1/2):111-143.

2003. "More Evidence for Dating the Sumtsek in Alchi and its Relations with

Kashmir." In Dating Tibelan Art. Essays on the Possibilities and Impossibilities of Chronology from the Lempertz Symposium, Cologne. Edited by I. Kreide-Damani. Wiesbaden: Ludwig Reichent Verlag.

Goepper, Roger, and Jaroslav Poncar. 1996. Alchi. Ladakh's Hidden Butdhist Sanctuary. The Stmisek. London: Serindia.

Himalayan Art 2004. TWebsite]. Shelly and Donald Rubin Foundation 2004 [cited 14th February 20041. Available from http:/ / www himalayanart.org/.

Howard, Kath. 1995. "Archaeological Notes on mChod-rten Types in Ladakh and Zanskar from the 11th-15th Centuries." Recent Research on Ladakh 4S5: 61-78. Edited by Henry Osmaston and Philp Denwood. London: School of Oriental and African Studies.

Howard, Neil F. 1989. "The Development of the Fortresses of Ladakh c. 950 to ca. 1650 A.D." East and West 39, 1-4:217-288.

. 1995. "The Fortified Places of Zanskar." Recent Research on Ladakh 4845: $79-99$.

Kapstein, Matthew T. 2000. The Tibetan Assimilation of Buddhism. Canversion, Contestation, and Memory. New York: Oxford University Press.

Khosla, Romi. 1979. Buddhist Monasteries in the Westem Himalaya. Bibliotheca Himalayica, Series III, Vol. 13. Kathmandu: Ratna Pustak Bhandar.

Klimburg-Salter, Deborah E. 1982. The Silk Route and the Diamond Path: Esoteric Buddhist Art on the Trans-Himalayan Trade Routes. Los Angeles: UCLA Art Council.

- 1988. "The Tucei Archives Preliminary Study, 2: The Life of the Buddha in Western Himalayan Monastic Art and Its Indian Origins: Act One." East and West $38(1-4): 189-214$.

1997. Tabo- a Lamp for the Kingdom. Earby Indo-Tibetan Buddhist Art in the Western Himalay. Milan/New York: Skira/Thames and Hudson.

Kossak, Steven M., and Jane Casey Singer. 1998. Sacred Visions. Early Paintings from Central 7ibet. New York: The Metropolitan Museum of Art. 
Kozicz, Gerald. 2002. "The Wanla Temple." In Buddhist Art and Tibetan Patronage Ninth iv Fourtenih Centuries, Edited by D. E. Klimburg-Salter and E. Allinger. Leiden: Brill.

Linrothe, Robert N. 1999. Ruthless Compassion. Wrathful Deities in Early Indo-Tibetan Esateric Buddhist Ant. London: Serindia Publications.

- 2001. "Group Portrait: Mahäsiddhas in the Alchi Sumtsek". In Embodying Wistom Art, Text and Interpretation in the History of Esoteri Buddhism. Edited by $\mathrm{R}$. Linrothe and H. H. Sørensen. Copenhagen: The Seminar for Buddhist Studies.

Linrothe, Robert N., and Melissa Kerin. 2001. "Deconsecration and Discovery: The Art of Karsha's Kadampa Chorten Revealed." Onimtations 32, 10:52-63.

Luczanits, Christian. 1996a. "Early Buddhist Wood Carvings from Himachal Pradesh." Orientations 27 (6):67-75.

. 1996b. "A Note on Tholing Monastery." Orientations 27 (6):76-77.

- 1998. "On an unusual painting style in Ladakh." In The Inner Asian Intemational Style 12th-14th Centuries. Papers presented at a panel of the 7 th seminar of the International Association for Tibetan Studies. Edited by D. E. KlimburgSalter and E. Allinger. Wien: Osterreichische Akademie der Wissenschaften.

- - 2001. "Methodological Comments Regarding Recent Research on Tibetan

Art." Review article of: Heller, Amy (1999) Tibetan Art. Tracing the Development of Spiritual Ideals and Art in Tibet 600-2000 A.D.Milano, Jaca Book. Wiener Zeitschrift fur die Kunde Sudasiens 45, 2001:125 145.

- 2002. "The Wanla Bkra shis gsum brtsegs." In Buddhist Ant and Tibetan Patronage Ninth to Fotreenth Centuries. Edited by D. E. Klimburg-Salter and E. Allinger. Leiden: Brill.

. 2003a. "Art-historical aspects of dating Tibetan art". In Dating Tibetan Art. Essays on the Possibitities and Impossibilities of Chronology from the Lempertz Symposium, Cologne. Edited by I. Kreide-Damani. Wiesbaden: Ludwig Reichert Verlag.

2004. "Early Tibetan Clay Sculpture," Aziatishe Kimst 33, 2:2,-15.

2004. Buddhist Sculpure in Clay: Early Westem Himalayan Art, late 10th to early 13 th centuries. Chicago: Serindia.

Naudou, Jean. 1980. Buddhists of Kasmï. First English Edition. Delhi: Agam Kala Prakashan.

Neumann, Helmut F. 2002. "The Wheel of Life in the Twelfth Century Western Tibetan Cave Temple of Pedongpo." In Buddhist An and Thetan Patronage Ninth $t$ Foutenth Centures. Edited by D. E. Klimburg-Salter and E. Allinger. Leiden: Brill.

Orofino, Giacomella. 1990. "A Note on Some Tibetan Petroglyphs of the Ladakh Area." East and West 40, 1-4:173-200.

Pal, Pratapaditya. 2003. Himalayas. An Aesthetic Adventure. Chicago: The Art Institute of Chicago in association with the University of California Press and Mapin Publishing.

Pal, Pratapaditya, and Lionel Fournier. 1982. A Buddhist Paradise: The Murals of Alcht Westem Himalayas. Hong Kong: Visual Dharma Publ.

Panglung, Jampa Losang. 1983. "Die Uherreste des Klosters Nar ma in Ladakh." Contributions on Tibetan Language, History and Culture. Procedings of the Csoma de Korors Symposium held at Velm-Vienna, Austria, 13-19 September 1981:281-287, plate III-XIV.

Petech, Luciano. 1977. The Kingdom of Ladakh C. 950-1842 A.D. Vol. LI, Serie Orientale Roma. Roma: Istituto Italiano per il Medio ed Estremo Oriente.

Rossi, Anna Maria, and Fabio Rossi. 1994. Selection 1994. London: Rossi publications. 
Singer, Jane Casey. 1997. "Taklung Painting." In Tibetan Ant. Towards a defnition of style. Edited by J. C. Singer and P. Denwood. London: Laurence King Publ.

Snellgrove, David L., and Tadeusz Skorupski. 1977. The Cultaral Heritage of Ladakh, 1 . Central Ladakh Warminster: Aris \& Phillips.

- - 1980. The Cultwal Heritage of Ladakh, 2. Zangskar and the Caute Temples of Ladakh. Warminster: Aris \& Phillips.

Stein, Marc Aurel. 1900 (repr. 1989). Kalhana's Rajatarangint, a chronicle of the Kings of Kámīt. 2 vols. Delhi: Motilal Banarsidass.

Uhlig, Helmut. 1976. Buddhistische Kunst aus dem Himalaya. Kaschmir-Ladakh-Tibet-NepatBhulan. Berlin: Kunstant Berlin-Tempelhof.

Vitali, Roberto. 1996. "Ladakhi Temples of the 13th-14th Century: Kan-ji tha-khang in sPu-rig and its Analogies with Gu-ru lha-khang." Kailash 18, 3\&4:93-106.

Vohra, Rohit. 1993. "Dating of a Maitreya Relief in the mid-8" Century from Sumda Chen." South Asian Studtes 9:97-103.

Yang, Han-sung, Yün-hua Jan, Shotaro Iida, and Laurence W. Preston. 1984. The Hye Ch'o diary: memoir of the pilgrimage to the five regions of India. Vol. 2, Religions of Asia Series. Berkeley, California/Seoul, Korea: Asian Humanities Press/Po Chin Chai. 


\section{LADAKHI HISTORIES Local and Regional Perspectives}

EDITED BY

JOHN BRAY

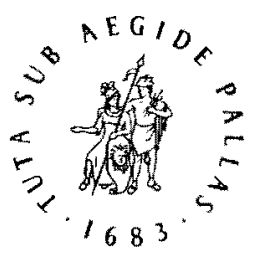

BRILL

LEIDEN - BOSTON

2005 
This book is printed on acid-free paper.

\section{Library of Congress Cataloging-in-Publication Data}

A C.I.P. record for this book is available from the Library of Congress.

ISSN $1568-6183$

ISBN 9004145516

O Copyright 2005 by Koninkliyke Bril NV, Leiden, The Netherlands Koninkigke Brill $\mathrm{NV}$ incorporates the imprints Brill Academic Publishers, Martinus Nighoff Publishers and VSP.

All rights reserved. No part of this publication may be reproduced, translated, stored in a retrieval system, or transmitied in any form or by am means, electronic, mechantcal, photocopying, recording or otherwise, without prior written permission from the publisher.

Authorization to photocopy items for internal or personal use is granted by Brill provided that the appropriate fees are paid directly to The Copyright Glearance Center, 222 Rosetwod Drive, Suite 910 Danvers, MA 01923, USA.

Fees are subject to change.

PRINTED IN THE NETHERLANDS 


\section{CONTENTS}

LIST OF ILLUSTRATIONS ..................................vii

ACKNOWLEDGEMENTS ................................. ix

JOHN BRAY - Introduction: Locating Ladakhi History .............. 1

PHILIP DENWOOD - Early Connections between

Ladakh/Baltistan and Amdo/Kham............................... 31

BETTINA ZEISLER - On the Position of Ladakhi and Balti in the Tibetan Language Family......................................4

CHRISTIAN LUCZANITS-The Early Buddhist Heritage of Ladakh Reconsidered ........................................65

ROBERTO VITALI-Some Conjectures on Change and Instability during the One Hundred Years of Darkness in the History of La dwags (1280s-1380s) .............................97

NEIL HOWARD-Sultan Zain-ul Abidin's Raid into Ladakh ......125

JIGAR MOHAMMED - Mughal Sources on Medieval Ladakh... 147

PETER SCHWIEGER - Documents on the Early History of He-na-ku, a Petty Chiefdom in Ladakh.............................16

NICOLA GRIST - The History of Islam in Suru .................175

TASHI STOBDAN-Gyajung Nagpo........................ 181

PETER MARCZELL - Dr. James G. Gerard's Unfulfilled

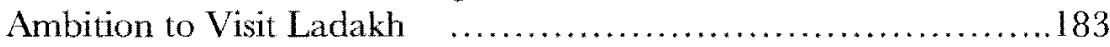

PETER MARCZELL-Csoma Körösi's Pseudonym..............203 
NEIL HOWARD - The Development of the Boundary between the State of Jammu \& Kashmir and British India, and its Representation on Maps of the Lingti Plain...

K. WARIKOO-Political Linkages between Ladakh and Eastern Turkestan under the Dogras during the $19^{\text {th }}$ Century...

JOHN BRAY - Early Protestant Missionary Engagement with the Himalayan Region and Tibet

CHRISTIAN HEYDE - The Early History of the Moravian Mission in the Western Himalayas: the Life and Work of Wilhelm and Maria Heyde

A. H. FRANCKE - Schools in Leh. Translated, with an Introduction by Gabriele Reifenberg.

POUL PEDERSEN - Prince Peter, Polyandry and Psychoanalysis

JANET RIZVI - Trade and Migrant Labour: Inflow of Resources at the Grassroots

\section{JACQUELINE FEWKES \& ABDUL NASIR KHAN - - Social} Networks and Transnational Trade in early $20^{\text {in }}$ Century Ladakh

NAWANG TSERING SHAKSPO - The Life and Times of

Geshe Ye-shes-don-grup

ERBERTO LO BUE - Lives and Works of Traditional

Buddhist Artists in $20^{\text {th }}$ Century Ladakh. A Preliminary Account...353

FERNANDA PIRIE - The Impermanence of Power: Village

Politics in Ladakh, Tibet and Nepal....

CONTRIBUTORS. 395 